\title{
A RESEARCH ON THE FUNCTION AND USABILITY OF HISTORICAL URBAN PARKS: CASE STUDY OF SHAH GOLI PARK, TABRIZ, IRAN
}

\author{
GÖKER, P. ${ }^{*}$ - CENGIZ HeRgUL, Ö. C. - KAHVECI, H. \\ Department of Interior Architecture and Environmental Design, Faculty of Fine Arts and \\ Design, Bilecik Şeyh Edebali University, Bilecik, Turkey \\ (e-mails: ozlem.hergul@bilecik.edu.tr; hilal.kahveci@bilecik.edu.tr) \\ *Corresponding author \\ e-mail: parisa.goker@bilecik.edu.tr \\ (Received $5^{\text {th }}$ Dec 2018; accepted $4^{\text {th }}$ Feb 2019)
}

\begin{abstract}
In this study, the recreational opportunities, which were created by the Shah Goli Park for the users in terms of its functionality, having a historical and unique characteristic, which is located in Iran, Tabriz, are analyzed. Accordingly, its availability for the local people is examined, as well. The data collection tool is in the form of a questionnaire. The objective of this questionnaire is to define the park availability factors for those, who visit the Shah Goli Park. The options with regards to the availability of the park were on socialization, physical activity, nature involvement and relaxation. The respondents were asked to address questions in order to show their preferences within the scope of a 5-point Likert scale $(1=$ Strongly disagree, $2=$ Disagree, $3=$ Don't know, $4=$ Agree, and $5=$ Strongly agree $)$ and the park's availability preference were measured using 14 items. Survey-analysis and questionnaire processes of the study were carried out in July-2018. The gathered data was subjected to an analysis by utilization of normal statistical methods within SPSS version: A set of park availability items were defined using the factor analysis, in order for designating the main and underlying factors, followed by a group mean comparison (t-test) in order to identify the differences between the demographic information and availability factors.
\end{abstract}

Keywords: land use, recreation area, open-green spaces, sustainability, historical parks

\section{Introduction}

Parks and open spaces, offering significant social and environmental functions, are valued leisure and amenity resources in cities. Urban parks are critical components within the metabolism of cities as well as the core scenes for open-air leisure communal activities. Historically, the functions of urban parks have been connected to leisure and aesthetics, but with the change of the surroundings and necessities of urban centres, leisure now includes sport activities, with the consequent implementation of fitness equipment, jogging tracks and sport courts (Almidia et al., 2018). Also, urban parks play a unique and indispensable role in providing public spaces and recreation opportunities for urban populations (Chan et al., 2018). As one of the most complex processes, overcrowding and unplanned growth are experienced, which raises concerns on the cities' sustainability, thus questioning how sustainable cities could be achieved. The objective of this study is to identify the potential advantages of historical urban green spaces with regards to the urban sustainability concept. In consequence, we consider sustainability concept, along with sustainable development, heritage, urban green spaces and quality of life and well-being as the main outline of the study, which are discussed in the following chapters. Urbanization processes, gathering pace with the growth of industrialization, has led the transformation of living areas of people from rural to urban. Today, in many of our large cities, witnessing the urbanization and 
industrialization movements; the structural density, increasing in parallel with the population growth, along with other unplanned developments, improper selection of settlement areas, has led the connection of urban with the rural to be ruptured, thus causing the open and green spaces in urban areas to diminish (Gürbüz and Y1lmaz, 2017). Open and green spaces, in other words "parks", having the potential to freshen up the people, instill a new dynamic, particularly providing the opportunity to be involved in recreational activities in megacities, facing with physical, social, biological and environmental problems, are deemed required (Y1lmaz et al., 2007).

The phenomenon "city" can be described not only as a physical, but also as social, political, economical and cultural production areas (Altuntaş, 2012) - a dynamic concept evolving from simple to complex, bearing various meanings from past to date (Topal, 2004). In this context, cities are the complex structures, comprising in the interface of a number of different subjects like land use, demographical qualifications, social and cultural structure, economical characteristics, historical and environmental subjects. In a highly dynamic and variable urban system, it is quite challenging to complete the designing and planning processes one level having the ability to come up with solutions against problems. In this system, the first time the problems became a current issue concerning the urban areas that change in time based on the socioeconomical and cultural structure of the society, characterized as the complete areas used by those urbanized on the urban land and where the urban-related events occur, and where the social or personal needs are met, was in the second half of 20th century, leading the physical and social problems to come to the forefront (Oktay, 2007). However, each and every characteristic is directly related to those urbanized in and of itself, which turns into a system running after being planned and designed as a whole, focusing on people (Akyol, 2006).

\section{Urban spaces}

More than half of the world's population nowadays live in cities. With more people coming to live and work in cities, urban public open spaces become even scarcer. Urban open spaces, such as squares, green spaces, or parks can provide environmental, ecological, social and economic benefits to cities and are indispensable for healthy urban living (Chen et al., 2015).

The first communities started to put down the roots in naturally enriched areas, along with those that were protected against natural powers, which were selected to meet their nutrition and accommodation requirements, as the most fundamental needs of people. Where people started to feel committed to an area, they also started to intervene the physical environment more, which emerged the need to build relatively more permanent structures. Having been experienced for centuries, this matter has reached to its peak point in today's world and led the emergence of modern cities (Özbilen, 1991; Çınar, 2008). Yet, increasing human population and rapid development of urbanization led to the destruction of nature and green areas (Yazıc1, 2015; Özdemir, 2007). In the case of the urban environment, it is both possible to define the city as one single ecosystem and to see the city as composed of several individual ecosystems, e.g. parks and lakes. Bolund and Hunhammar (1999) identify seven different urban ecosystems which we call natural, even if almost all the areas in cities are manipulated and managed by man. The ecosystems comprise of street trees, lawns/parks, urban forests, cultivated land, wetlands, lakes/sea, and streams (Bolund and Hunhammar, 1999). Rogers' reports that there is a continuing trend towards urbanization, both in Britain (in 1991, over $80 \%$ of 
the population lived in towns and cities of over 10,000 people) and world-wide (today nearly $50 \%$ of the world's population live in urban settlements) (Thompson, 2002). Open spaces such as parks, playgrounds and plazas have been criticized in the past as a largely failing to serve their intended uses and users. Non-use of parks, vandalism, and outdated facilities are examples of problems commonly identified with urban open spaces. Indeed, urban open research originated from public awareness of the social failure of many urban open spaces (URL 1, 2018).

Urban green spaces play a remarkable role to reduce bad consequences of the rapid rate of urbanization ( $\mathrm{Li}$ et al., 2017). Green spaces and other nature-based solutions offer innovative approaches to increase the quality of urban settings, enhance local resilience and promote sustainable lifestyles, improving both the health and the wellbeing of urban residents. Parks, playgrounds or vegetation in public and private places are a central component of these approaches and can help to ensure that:

- Urban residents have adequate opportunities for exposure to nature;

- Urban biodiversity is maintained and protected;

- Environmental hazards such as air pollution or noise are reduced;

- The impacts of extreme weather events (heatwaves, extreme rainfall or flooding) are mitigated;

- The quality of urban living is enhanced;

- The health and well-being of residents are improved (WHO, 2018).

There is evidence that rural residents experience a health disadvantage compared to urban residents, associated with a greater prevalence of health risk factors and socioeconomic differences compared to urban and suburban populations, along with the evidence of a health disadvantage associated with living in rural areas. Research in Canada has identified higher mortality rates, decreased life expectancy, greater incidence and prevalence of morbidity, and poorer self-reported health status in rural populations. For example, life expectancy at birth is at least 2 years less for men in rural areas compared to urban areas and the risks of death from circulatory disease or respiratory disease are as much as $10 \%$ higher in rural areas. This health disparity may be the result of differences in health risk factors, including health behaviours and socioeconomic status (SES). Additionally, differences in activity patterns between urban and rural populations may potentially lead to differences in exposure and risk(s) related to environmental contaminants, further contributing to the health disparity (Matz et al., 2015).

\section{Urban parks}

For the recreational life and outdoor activities of people, urban parks play a critical role. Parks are generally used by people in urban areas. As a result of the outdoor environment complexity, scarcely any steps have been taken to understand the impact of thermal environment on how people use the outdoor spaces (Thorsson et al., 2004; Çınar, 2008; Polat and Güngör, 2013). The sustainability and regeneration strategies of cities essentially focus on man-made and built components within the urban environment, when compared, attention to the natural components and urban structure's green spaces are still limited (Chiesura, 2004). However, it is discussed that the urban parks and open green spaces are of a strategic significance within the scope of the quality of our increasingly urbanized society's life. As a matter of fact, increasing 
empirical evidence shows that the presence of natural assets (i.e. urban parks and forests, green belts) and components (i.e. trees, water) within urban contexts contribute to the quality of life under quite a lot of manners. Additionally, critical environmental services like air and water purification, wind and noise filtering or microclimate stabilization, the natural areas provide social and psychological service that are of vital importance with regards to the liveability of modern cities, along with the well-being of urban dwellers. Park experience bears the potential to reduce stress, enhancing contemplativeness, rejuvenate the city dweller, thus providing a sense of peacefulness and tranquility (Kaplan, 1983; Chiesura, 2004). Parks are important recreation areas within open and green area system (Onsekiz and Emür, 2008; Aksoy and Akpinar, 2012). Providing the societies with the opportunity to perceive the nature itself, while being used for recreational purposes for centuries, the parks have gained a gradually increasing importance and value, particularly in urban environments. Formed based on cultural values, political and socio-economical structure, the urban parks have taken its form with social changes thanks to aforementioned characteristics, thus acting as a reflector for them, as well (Kurtaslan, 2017).

Urban parks constitute an important place of leisure and recreation for city residents. They are also important because they tend to be among the few places that offer urban dwellers opportunities for contact with nature and vegetation (Mahrous et al., 2018). Urban parks offer multi-dimensional urban ecosystem functions as well as spaces for human-environment connection (Chan et al., 2018). Urban open-green spaces provide many advantages like creating areas for recreational activities, reducing the air pollution, balancing the atmospheric oxygen and carbon dioxide rate, regulating the micro-climate, minimizing the floods, providing shielding against noise and wind, creating living space for wild-life, contributing positively in physical and mental health, etc. (Waterman and Wall, 2009; Yazıc1, 2015). People in industrialized countries spend on average less than $10 \%$ of their time outdoors (Lee and Kim, 2015). One vital role that urban parks play is providing space for the expression of diversity, both personal and cultural; this raises issues of democratic provision for and access to public open space. It suggests, inter alia, that the role of the urban street as public space may need to be re-thought. The social and cultural values of open space include attitudes towards nature and the desire for connection with it, as well; contemporary understandings of ecology offer new insights into ways to serve both human needs and the broader ecological framework of urban open space structures (Thorsson et al., 2004)

Urban parks are valuable urban green areas serving for citizens to keep away from the stressful city life and relax thanks to its social and environmental functions. For this reason, the importance of urban parks is obvious with its advantages like providing an aesthetical view, minimizing the noise, clearing the air, along with its micro-climate affect and pollution control (Lam et al., 2005). Urban parks are green areas that keep people out of the intense and boring impact of a city, while providing various recreational benefits (Zaloğlu, 2006). Urban parks can also be described as open-green spaces, created with the combination of natural and cultural concepts towards meeting the active and passive recreations needs of those urbanized (Kizılaslan, 2007). Planning and management of urban parks are of significance for urban development. Urban parks possess critical ecological, social and economical functions. Therefore, social life styles, values, attitudes towards the nature and sustainability will increase the demand on urban parks in the future. Parks and open areas should not be deemed as luxury within the city (Loures et al., 2007). Urban parks are public service areas that are of crucial importance 
in re-establishing the ruptured relations of people with the nature itself, developing as a condition to urbanization within the complex urban organization, along with undertaking various functions (Kizılaslan, 2007).

\section{Urban park standards}

The factors that designate the standards required for the park areas in line with the life style of our time can be summarized as follows:

- Population,

- City size,

- Geographical location,

- Climate,

- Distance and density of use (Polat, 2006).

According to Oğuz (1998), park and green area sizes vary depending on every country, settlement and their needs. The need for green area increases as directly proportional to the population and structure.

The changes of open-green spaces are shown in Table 1 (Özkır, 2007) - Open Green Spaces' Sizes and Locations (Tümer, 1976; Müftüoğlu, 2008; Yazgan, and Khabbazi, 2013).

Table 1. Open-green spaces' sizes and locations (Tümer, 1976; Müftüoğlu, 2008)

\begin{tabular}{c|c|c|c|c|c}
\hline \multirow{2}{*}{ Park areas } & \multicolumn{2}{|c|}{$\begin{array}{c}\text { Population criterion } \\
\text { da/per capita }\end{array}$} & \multicolumn{2}{c|}{ Area size criterion (da) } & \multicolumn{2}{c}{$\begin{array}{c}\text { Its place in recreation } \\
\text { areas }\end{array}$} \\
\cline { 2 - 5 } Quarter Park & Minimum & Optimal & Minimum & Optimal & 40 \\
\hline Neighborhood park & 6 & 12 & 20 & $\begin{array}{c}\text { As a single unit or within } \\
\text { neighborhood parks }\end{array}$ \\
\hline Urban park & 1 & 14 & 200 & 400 & $\begin{array}{c}\text { As a single unit or within } \\
\text { neighborhood parks }\end{array}$ \\
\hline Regional park & 4 & 12 & 3000 & 4000 & $\begin{array}{c}\text { Main recreation area in the } \\
\text { urban fabric }\end{array}$ \\
\hline
\end{tabular}

On the other hand, classifies the parks based on the number of residences to which the park serves, dwelling unit and size (Table 2) (Özkır, 2007; Müftüoğlu, 2008; Yazgan and Khabbazi, 2013) and also represent the national recreation and park board's standards on parks (Table 3).

Table 2. Figures concerning the sizes of park areas within the city (Özkır, 2007; Müftüoğlu, 2008; Yazgan and Khabbazi, 2013)

\begin{tabular}{c|c|c|c}
\hline Parks & Number of residences addressed & Required dwelling unit & Size \\
\hline Quarter Park & $700-1000$ & Primary school & $1-4$ ha \\
Neighborhood park & $1000-5000$ & District & $4-20$ ha \\
Urban park & $5000-10000$ & City & $20-50$ ha \\
Regional park & $20000-30000$ & Region & 200 ha and over \\
\hline
\end{tabular}


Table 3. National Recreation and Park Board's Standards on Parks (Özkır, 2007; Yazgan and Khabbazi, 2013)

\begin{tabular}{c|c|c|c|c}
\hline Type & da/1000 & Size & Population served & Accessibility \\
\hline Quarter Park & 10 & $20-80$ & $2000-10000$ & $400-800 \mathrm{~m}$ \\
\hline Neighborhood park & 10 & $80-400$ & $10000-50000$ & $800-4800 \mathrm{~m}$ \\
\hline Urban park & 20 & Variable & Variable & 30 min of drive \\
\hline Regional park & 80 & 1000 and over & The entire population in small cities & 1 h of drive \\
\hline Private areas & \multicolumn{5}{c}{ No applicable standard. It comprises trees, roads, beaches, transcendental areas, etc. } \\
\hline
\end{tabular}

\section{The role of urban parks, quality of life and well-being}

Urban parks and green spaces play an important role for environmental services such as air and water purification, wind and noise filtering, and microclimate stabilization. They also provide social and psychological services, which are important for public well being (Urban areas are recognized as one of the key components of sustainable cities, and accordingly, creating more sustainable urban areas is the key to sustainability (Özdemir, 2007). Sustainable areas can be described as those, which are created to support sustainable living primarily focusing on the economic, environmental and social sustainability (Huseynov, 2005). This has a unique significance for urban green areas, tending to imply and symbolize a distinct set of ideals concerning the city's identity, along with its history and culture on one side, and its local economic growth on the other. In this context, the urban landscape is recognized as quite positively linked to sustainability policies (Beck, 1992; Sachs, 1995; Ferris, et al., 2001; Loures et al., 2007). The empirical research, in addition to the theoretical study, has underlined the role of urban landscapes in the environmental, aesthetical, psychological, social and economical aspects of urban life (Grahn, 1985; Burgess et al., 1988; Conway, 2000; DeGraaf, 2003; Chiesura, 2004). Similarly, urban green spaces are recognized as the essential component within the scope of urban sustainability, for their beneficial services and also one possible step to the creation of sustainable urban environments. (Zhang et al., 2012). Hence, these aspects like "amount of urban green spaces per inhabitant," "public parks," and "recreation areas" are recognized to have strategic significance for improving the life quality (Teal et al., 1998), making the city livable, pleasant and appealing for citizens (Chiesura, 2004)

The term "well-being" has been defined in various ways using socio-economic, psychological, and psychosocial parameters as well as feelings of connectedness to nature (Bell, 2005; Dutcher et al., 2007). The World Health Organization (WHO, 2018) defines health and well-being as "a state of complete physical, mental and social wellbeing and not merely the absence of disease or infirmity". Greenberg (1985) suggests that wellness (or well-being) differs from health; in that, "it is the integration of physical, emotional, mental, spiritual and social health at any level of health or illness". The term "well-being" includes material security, personal freedoms, good social relations and physical health, whereas the term "health" includes biological, sociological, economic, environmental, cultural, and political factors (Walter et al., 2005). Based on this definition, a person might be regarded as achieving the status of well-being within one of the domains of health, which is defined as asymmetrical health (Greenberg, 1985). Well-being is defined in this study as an inner state of wellness that 
includes physical, social, mental, spiritual, and emotional states of consonance, which exist in healthy environments (Burns, 2006) or are achieved through connection or engagement with natural environments and green spaces.

Eventually, for making cities more sustainable, urban parks have the ability to play a key role, along with providing benefits for the habitat, air and water quality, and also letting the kind of high neighbourhoods densities, which are contributive in terms of lowering the energy consumption while increasing active, human powered transportation. Surely, it is critical to possess wide open spaces, and especially natural areas which provide habitat, as well as reinforcing the compact city design. Additionally, urban dwellers can be encouraged in order to appreciate the natural processes within their neighbourhoods, providing authentic facilities in which people are provided with the opportunity to gather either informally or more formally. Parks serve to connect people to the history of both the environment that was built, and also the natural processes in the area, as well. Altogether, these areas can be rick in cultural resources, allowing people to sustain the community life over time.

The present study aims to investigating the recreational opportunities, which were created by the Shah Goli park for the users in terms of its functionality, having a historical and unique characteristic, which is located in Iran, Tabriz.

\section{Materials and methods}

\section{Case area: location, boundaries and geographical characteristics of Tabriz City}

Tabriz is located at $38^{\circ} 8^{\prime}$ and $46^{\circ} 15^{\prime}$ East of Greenwich with an area of about $131 \mathrm{~km}^{2}$ (Ghorbani, 2006). The city is located in $1200 \mathrm{~m}$ above sea level (Rahimi, 2006)'. In the winter, the average temperature is $12.4^{\circ} \mathrm{C}\left(88.4^{\circ} \mathrm{F}\right)$ and in the summer the average temperature can be up to $34.1^{\circ} \mathrm{C}\left(110.1^{\circ} \mathrm{F}\right)$. Lack of water resources is the most important climatic problem in the city; meanwhile the annual rainfall (snow and rain) is only about $321 \mathrm{~m}^{2}$ and most of the rains occur during winter and spring. Despite harsh weather, the population of this city is $1,579,312$, according to the Census Central Organization of Iran (Fig. 1).

\section{Data collection instrument}

The data collection tool is in the form of a questionnaire. The objective of this questionnaire is to define the park availability factors for those, who visit the Shah Goli Park. The options with regards to the availability of the park were on socialization, physical activity, nature involvement and relaxation. The respondents were addressed questions in order to show their preferences within the scope of a 5-point Likert scale (1 $=$ Strongly disagree, $2=$ Disagree, $3=$ Don't know, $4=$ Agree, and $5=$ Strongly agree) and the park's availability preference were measured using 14 items.

\section{Data analysis}

The gathered data was subjected to an analysis by utilization of normal statistical methods within SPSS version: The set of park availability items were defined using the factor analysis, in order for designating the main and underlying factors, followed by a group mean comparison (t-test) in order to identify the differences between the demographic information and availability factors. 


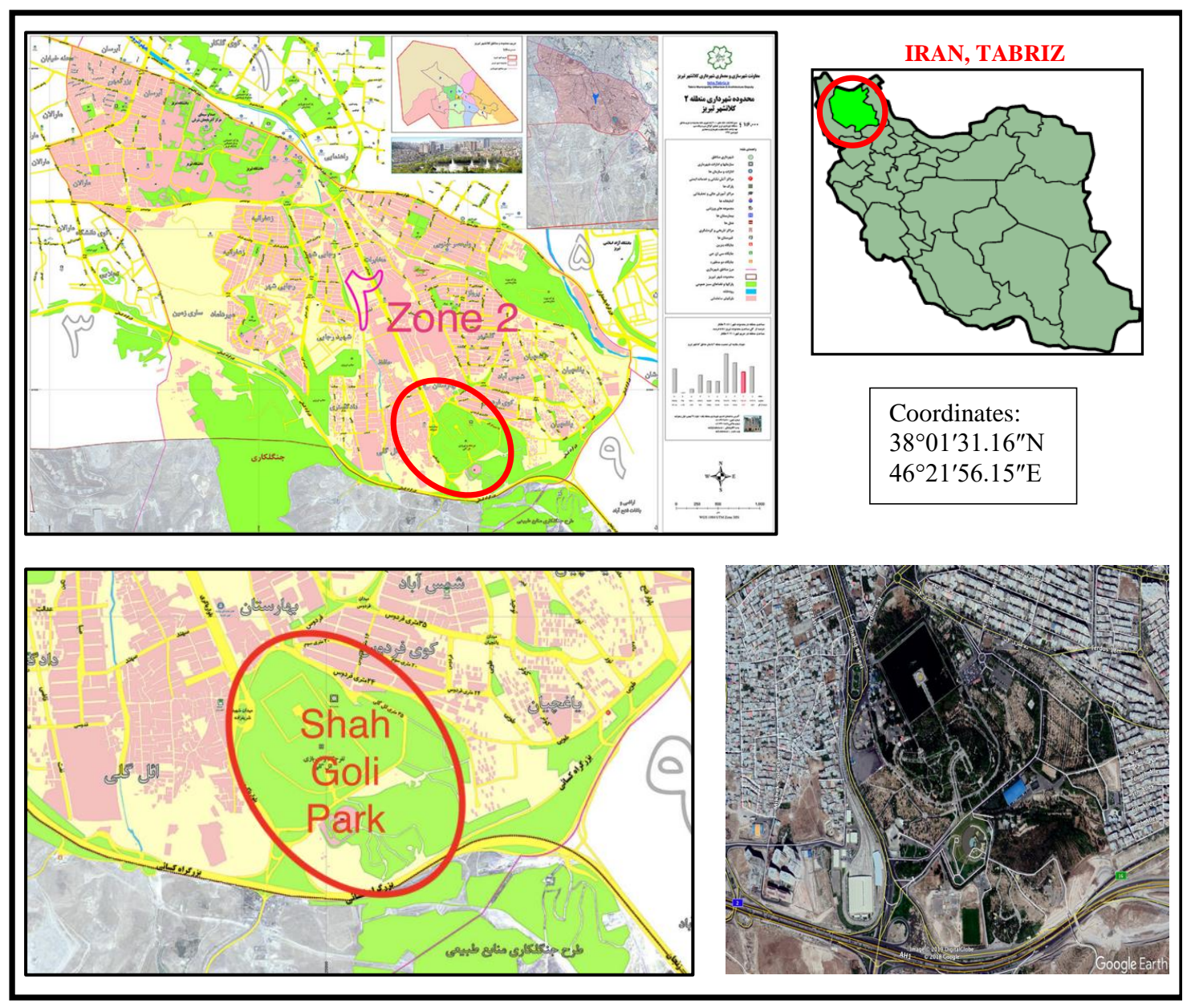

Figure 1. Location of Shah Goli Park (Tabriz City Regional Planning, 2018)

\section{History of urban park in Iran}

Iran's history of public space can be traced from the period when the Persian Empire around 500 years B.C. Throughout the history public spaces were being used for various purposes like a place for national ceremonies, declaring important news, crowning ceremonies, etc. During $14^{\text {th }}$ century A.D., public spaces like "Chahar Bagh" were the most essential parts of the city. In this period, public spaces were used as a place of social communication, as well as national and religious ceremonies. Additionally, Persian gardens were introduced as an area in order for experiencing the nature, as well. During the early $20^{\text {th }}$ century A.D., in Iran, including Tabriz, for recreation and socialization of people, Persian gardens started to be recognized as public urban parks in most of the large cities (Romianfar, 2008). What is more is that these public spaces can be recognized as multipurpose areas, too (Hami et al., 2011). Urban parks were not that common in the cities of Iran because of the insufficient amount of water resources; hence, a vast majority of available green spaces in the traditional cities were garden, generally built on a private land. Following the swift and modern urbanization of Persian cities, urban parks became popular choices for accessibility to green space. As per a previous study, people used to prefer urban parks mostly for passive entertainment and individual active activities like hiking (Hami et al., 2011), notwithstanding that, 
some of the parks possess sport facilities like volleyball and tennis courts for the visitors. In general, urban parks in Iran are recognized as places for nature appreciation (Hami et al., 2011; Rostami et al., 2017) and social interactions like family gatherings (Hami et al., 2011). Therefore, landscaping of urban parks require considering up of public demands and needs.

\section{Shah Goli Park}

Shah Goli Park is also known as the "Old Park" in Tabriz and was built as a royal park by an unknown king in 1785 (Wilber, 1979). This was later declared as a public urban park in 1930 (Romianfar, 2008). El Goli covers an area of 60.7 Hectares (150 acres) (Ghorbani, 2006) and located in the Southwest part of Tabriz. Construction of the original building ponds is ascribed to the reign of Sultan Yaghoob Aghkoyunlular and consider its development from the Safavid period. Completion of especial esplanade and mansion for courtiers and its prosperity is ascribed to the time of Champion Mirza, the son of Abbas Mirza regent- who was the ruler of Azerbaijan. The Safavid dynasty in the pool Shah Goli was the largest water reservoir in the garden. Aghkoyunlular and Safavid and Qajar periods all within the catchment area of sand was empty and it was drawn on the walls of stone and lime. After the Qajar era this area was transferred to Tabriz municipality be a public walkway. With the construction of five-star hotel Elgolu Pars, this area has the international aspect and the space agencies of Tabriz city has become one of the most beautiful public parks (Rostami, 2017). In 1930, renovation was done to the park by Tabriz Municipality and it became a public park (Romianfar, 2008). During the renovation, an artificial lake was added and it becomes a prominent feature of Shah Goli Park. The artificial lake is $213.23 \mathrm{~m} \mathrm{(700} \mathrm{ft)} \mathrm{long} \mathrm{and} 213.23 \mathrm{~m}$ (700 ft) wide covering $54,675 \mathrm{~m}^{2}$ of area. In the eastern side, some terraces have been built and a row of poplars planted along the walls. The park was further expanded in 1989 and 1996 with new features added (Fig. 2) (Romianfar, 2008).

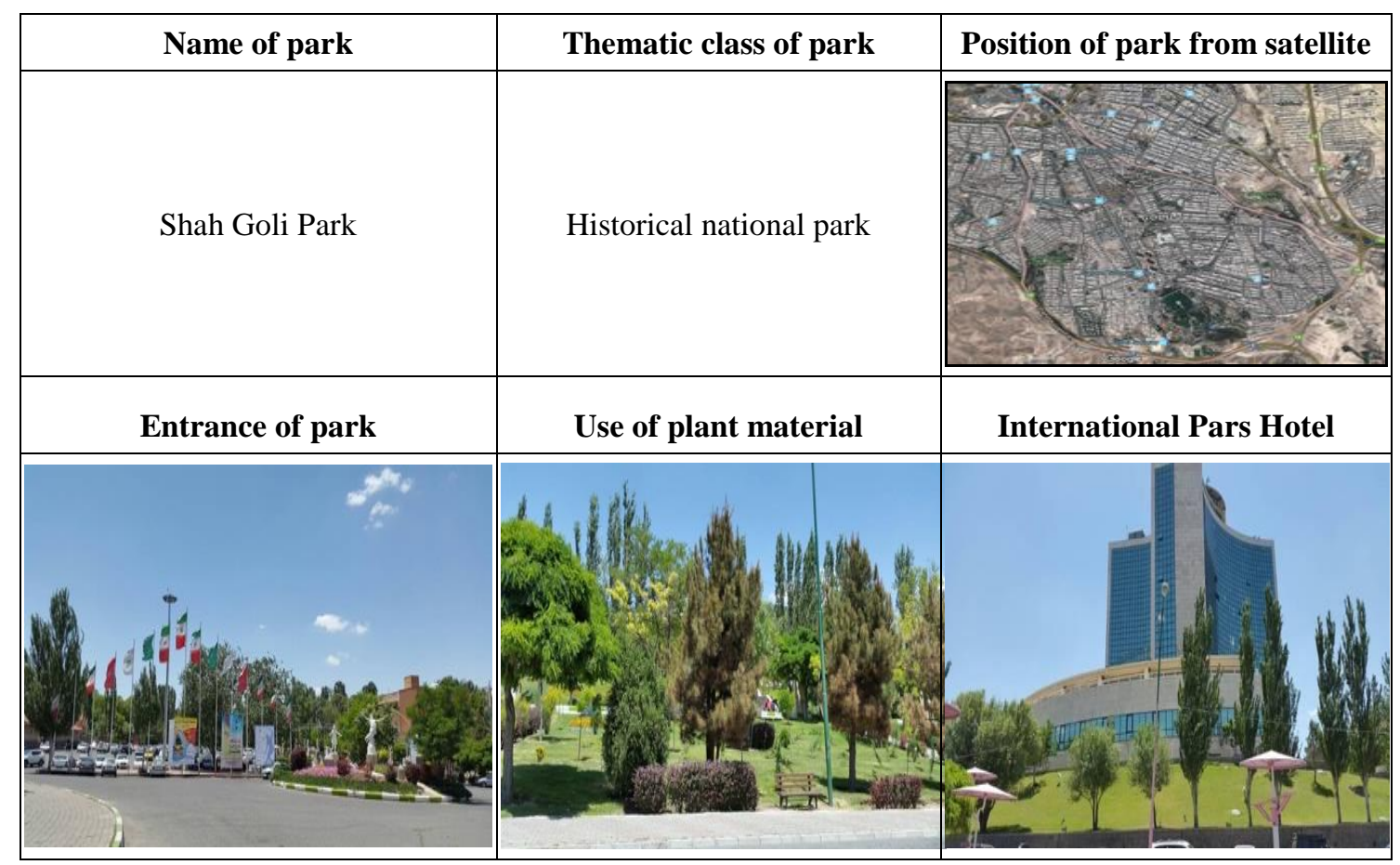




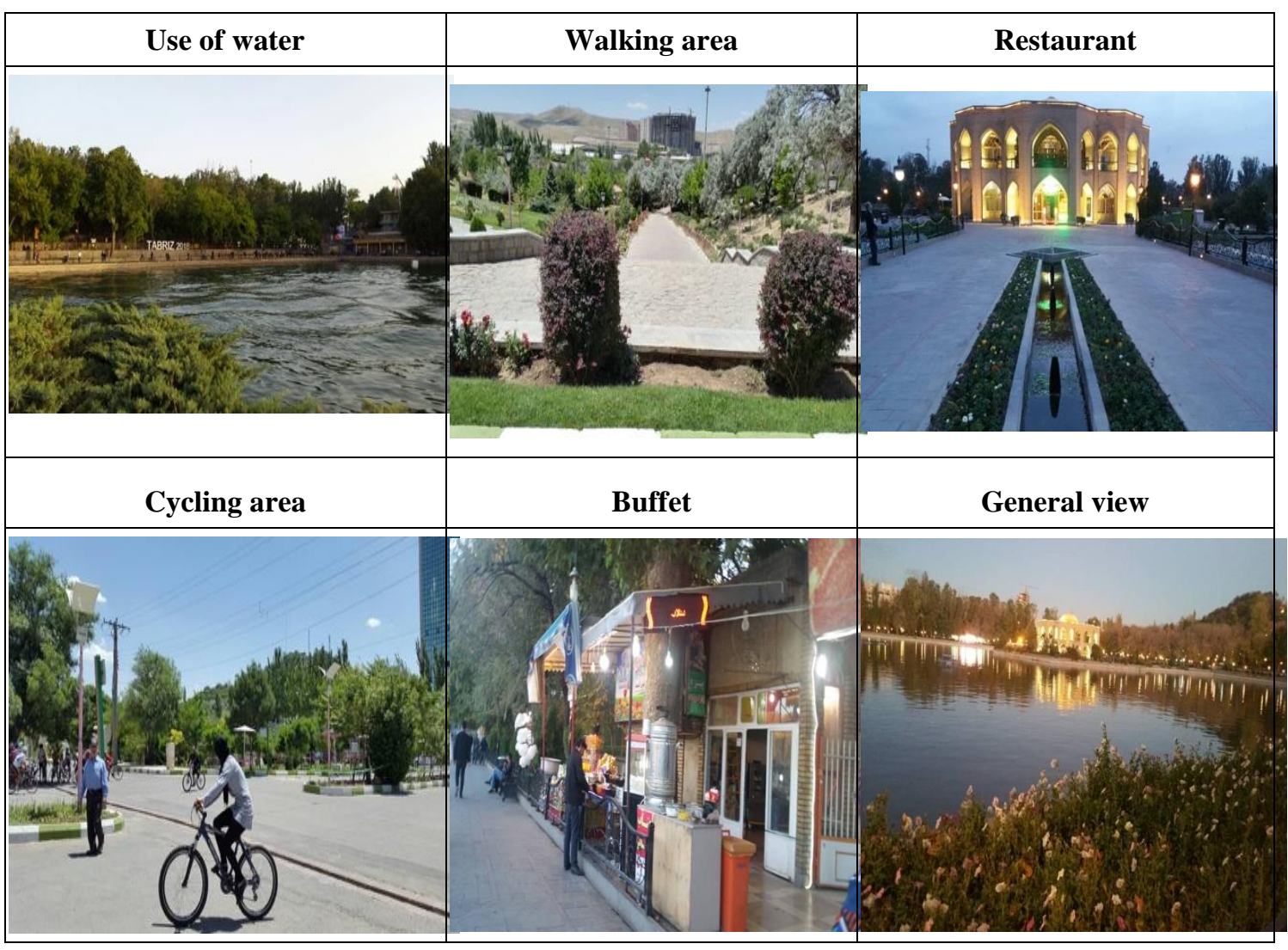

Figure 2. View of Shah Goli Park (Original, 2018)

\section{Results}

\section{Demographic profile of the participants}

A total of 296 participants took part in the study. Table 4 shows the participants' demographic information. The majority of participants were male $(55.1 \%, \mathrm{n}=163), 18$ 30 years old $(47.3 \%, \mathrm{n}=140)$, married $(58.1 \%, \mathrm{n}=172)$, and had university level education $(52.02 \%, \mathrm{n}=154)$ (Figs. 3-6).

Table 4. Demographic description of the survey

\begin{tabular}{c|c|c}
\hline Variables & Number & Percent \\
\hline Gender & 296 & 100 \\
Male & 163 & 55.1 \\
Female & 130 & 43.9 \\
\hline Age & & \\
$18-30$ & 140 & 47.3 \\
$31-40$ & 87 & 29.4 \\
$41-50$ & 36 & 12.2 \\
Above 50 & 30 & 10.1 \\
\hline Marital status & & \\
Single & 121 & 40.9 \\
Married & 172 & 58.1 \\
\hline Education & & \\
Guidance school & 25 & 8.4 \\
Under diploma & 29 & 9.79 \\
Diploma & 88 & 29.7 \\
University & 154 & 52.02 \\
\hline
\end{tabular}




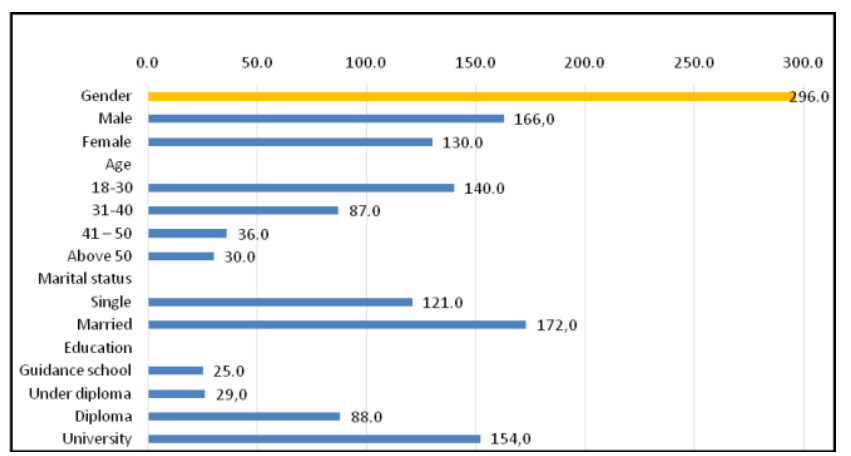

Figure 3. Description of survey by gender, sex, age, marital status and education

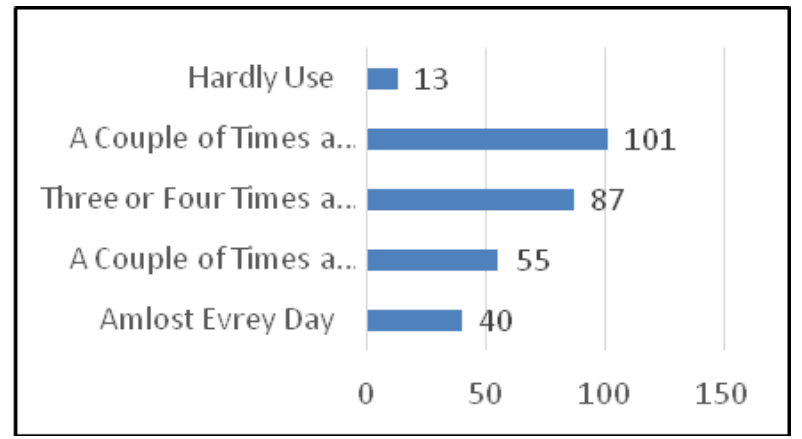

Figure 4. Usage frequency of Shah Goli Park

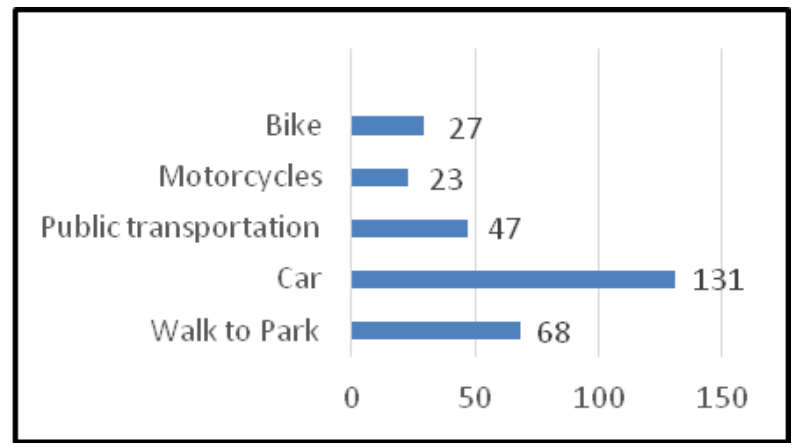

Figure 5. Type of access to Shah Goli Park

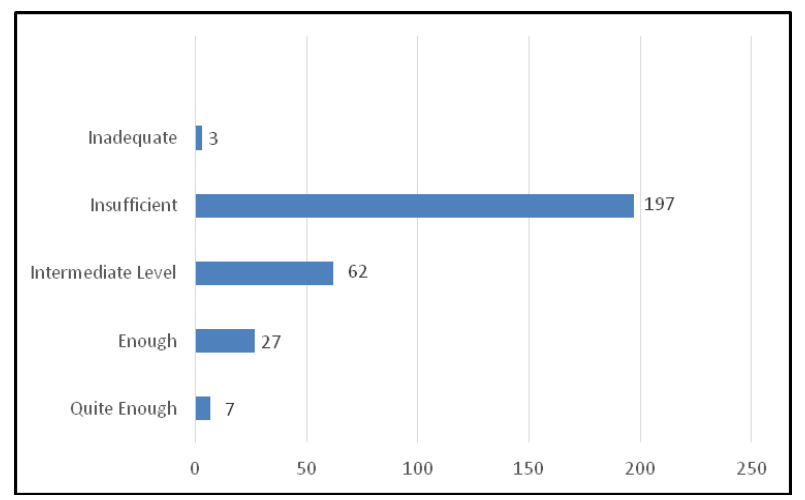

Figure 6. According to users, Shah Goli Park's field competence

APPLIED ECOLOGY AND ENVIRONMENTAL RESEARCH 17(2):3147-3163.

http://www.aloki.hu • ISSN 15891623 (Print) • ISSN 17850037 (Online)

DOI: http://dx.doi.org/10.15666/aeer/1702_31473163

(C) 2019, ALÖKI Kft., Budapest, Hungary 


\section{Preferences for park usability}

What is shown in the collected data is that "enjoy the landscape view" (mean $=4.72$, $\mathrm{sd}=.55$ ) has the highest preference rate among the other activities for parks, followed by 'to walk in the park' and 'to exercise' (mean $=4.53, \mathrm{sd}=0.66)$, 'To watch water flow in the park' (mean $=4.46, \mathrm{sd}=.87$ ), 'To socialize with friends' (mean $=4.33$, $\mathrm{sd}=.83$ ), 'To sit under the trees shade' (mean $=4.37, \mathrm{sd}=.78)$, 'To socialize with friends' and 'To have dinner with family or friends in the park' (mean $=4.33, \mathrm{sd}=.83$ ), 'To picnic' $($ mean $=4.27, \mathrm{sd}=.93)$, 'To be with family' $($ mean $=4.04$, sd $=1.11)$, 'To play with children in the park' (mean $=3.93, \mathrm{sd}=.90)$, 'To socialize with people' $($ mean $=3.66, \mathrm{sd}=.1 .18)($ Table 5; Fig. 7). These results show the areas that the participants preferred for highly social and environmental activities in the park. It seems clear that people are not provided with adequate space for exercising and hiking in a crowded city like Tabriz, arising the need for them to go parks, along with open public spaces in order for hiking and similar activities

Table 5. Mean analysis for usability variables

\begin{tabular}{c|c|c}
\hline Variables & Mean & Std. dev. \\
\hline To walk in the park & 4.53 & 0.66 \\
To picnic & 4.27 & 0.93 \\
To watch water flow in park & 4.46 & 0.87 \\
To socialize with friends & 4.33 & 0.83 \\
To enjoy the landscape view & 4.72 & 0.55 \\
To rest and sit under tree shade & 4.37 & 0.78 \\
To be with family & 4.04 & 1.11 \\
To socialize with other people & 3.66 & 1.18 \\
To exercise & 4.53 & 0.66 \\
To play with children in the park & 3.93 & 0.90 \\
To have dinner with family or friends in the park & 4.33 & 0.83 \\
\hline
\end{tabular}

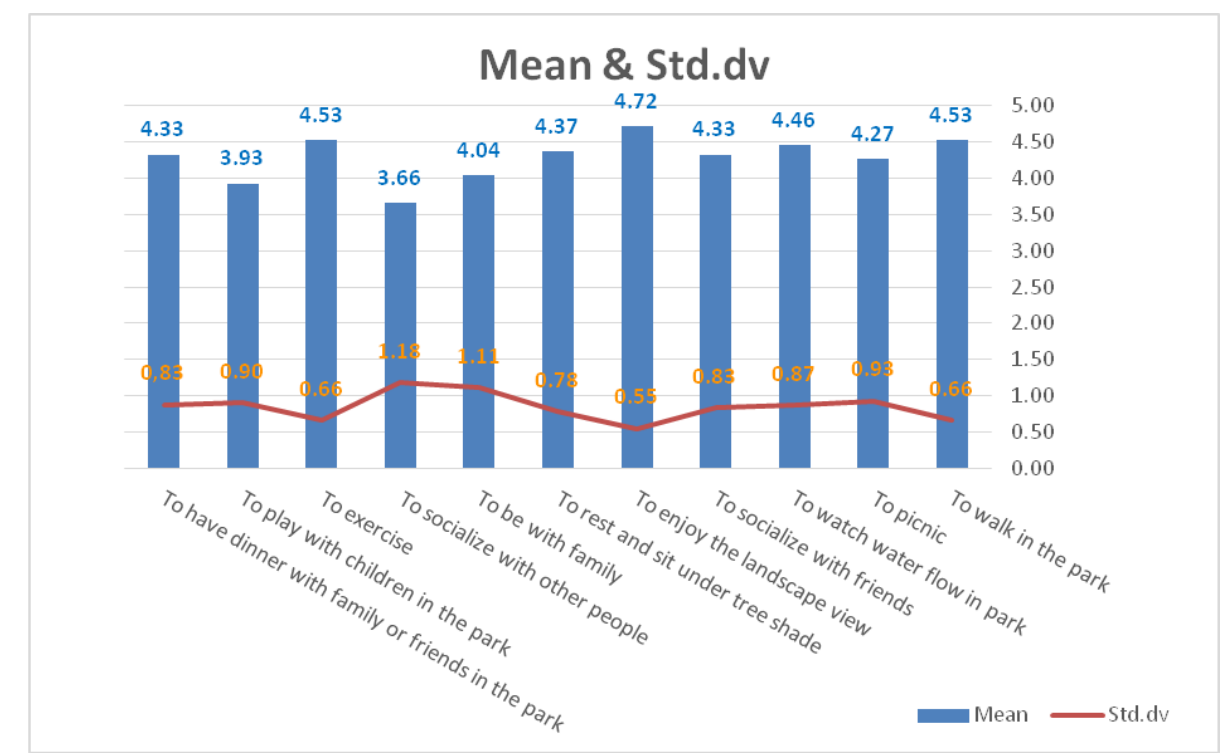

Figure 7. Mean analysis for usability variables 


\section{Park usability underlying dimensions}

In order to identify the underlying dimensions within the scope of park availability, a factor analysis was carried out on the collected data. Three dimensions were obtained following the analysis on the respective items (Table 6).

Activities like nature-related activities may seem appealing to more people for visiting the parks. What is interesting is that there is a relation between plants' contribution to activities done in urban park. A factor analysis on activity set forth that Social Activities (mean $=4.19$, sd $=0.69$ ), and five Environmental Activities (mean $=4.64, \mathrm{sd}=0.67)$ acquired the highest rate, respectively $($ Table 6$)$.

Table 6. Underlying dimensions of park usability

\begin{tabular}{c|c|c|c}
\hline Social activities & Factors & Mean & Std. dev. \\
\hline To be with family & & $\mathbf{4 . 1 9}$ & $\mathbf{0 . 6 9}$ \\
\hline To play with children in the park & .746 & & \\
\hline To socialize with friends & .623 & & \\
\hline To socialize with other people & .723 & & \\
\hline To exercise & .608 & & \\
\hline To have dinner with family or friends in the park & .595 & & \\
\hline Environmental activities & & & \\
\hline To have a picnic & & & \\
\hline To walk in the park & .701 & & \\
\hline To watch water flow in park & .607 & & \\
\hline To rest and sit under tree shade & .730 & & \\
\hline To enjoy the landscape view & .488 & & \\
\hline
\end{tabular}

\section{Discussion}

The role of historical parks as the provider of social services, along with its significance for city's sustainability has been determined in this research. For exploring the motives and perceptions of the visitors of Shah Goli Park, certain results of the questionnaire have been presented. Some of the concluded remarks are as follows:

To begin with, the study states that urban planning, along with the contributions it provides in tackling a number of detrimental environmental problems, which have been recently recognized as the characteristic of crowded city centers and urban environments, may be recognized as a premise in terms of creating sustainable urban life. Urban green spaces have the ability to gather people together, while increasing the public congregation and interaction along with increasing accessibility to public services and employment, which, by the way, may be the essential aims of sustainable urban policy.

Depending on the number of users, usage frequency, involved functional facilities and social carriage capacity of people, ecological carriage capacity of the area, the park's surface area may vary. These factors are directly related to the social and environmental structure of people. In this study, the survey was performed on 14 subjects in the park, with a total participant number that is equal to 296. A 
supplementary X2 significance test was carried out with over 296 questionnaires received from the visitors of park, of which results can be seen in Table 6. The aim of the study was to determine the individual features of users (gender, marital status, age, education) and differences among these features. From the results obtained, the individual features of 296 participants were as follows: for gender status, $55.1 \%$ of subjects was male and $43.9 \%$ was female; for marital status, $40.9 \%$ was married and $58.4 \%$ was single; for age, $47.3 \%$ was between $18-30,29.4 \%$ was between 31 and 40 , $12.2 \%$ was between 41 and 50 and $10.1 \%$ was above 50; for education level $8.4 \%$ was guidance school; $8.4 \%$ was under diploma, $29.7 \%$ was diploma and $52 \%$ was university graduate.

\section{Conclusion}

The results obtained set forth that the participants prefer to perform environmental activities like enjoying the landscape view, watching the water flow in the park and walking around the park. People seemed interested in direct involvement with the natural elements like plant materials and water, while carrying out the respective environmental activities. It is understood that green spaces and water features lead users to feel relieved, thus ensuring serenity in parks. The results indicate that the activities that are performed most frequently in urban parks are as follows: having a picnic, walking, sitting, admiring nature, and watching plant material scenes. So, it can be said for people that they wish to connect with green areas for entertainment and natural involvement in urban parks, attracting more people to visit parks. The study underlined the significance of plant material and water feathers arrangement and configuration within the scope of improving the social life of people. Additionally, activities that are performed by people in urban parks are required to be designed and planned in connection with the natural element's spatial configuration.

Considering the positive effects of open-green areas on human psychology, it can be clearly seen that recreative activities by people in green areas are of vital importance. The leading determinant in this matter is accessibility. People usually prefer going to parks and green areas that are close to where they live, but some people may choose to go distant places in line with the quality of time they spend. Increasing the ratio of urban green areas per capita will not only proportionally increase the options for towndwellers, but they will also be provided with the opportunity to access areas that offer different activities. Existence of green areas affects both the physical health thanks to the, for example, plants that clear the air, and psychological health of people. In this context the life quality in urban areas increases with green areas, which ensures improvement in the sense of belonging and well-being.

\section{REFERENCES}

[1] Aksoy, Y., Akpınar, A. (2012): Yeşil Alanların Kullanımı ve Yeşil Alan Gereksinimi Üzerine Bir Araştırma İstanbul İli Fatih İlçesi Örneği. - İstanbul Ticaret Üniversitesi Fen Bilimleri Dergisi 10(20): 81-96.

[2] Akyol, E. (2006): Kent Mobilyaları Tasarım ve Kullanım Süreci. - Basılmamış Yüksek Lisans Tezi, İstanbul Teknik Üniversitesi, Fen Bilimleri Enstitüsü, İstanbul.

[3] Almeida, C. M. V. B., Mariano, M. V., Agostinho, F., Lui, G. Y., Giannetti, B. F. (2018): Exploring the potential of urban park size fort he provision of ecosystem services to 
urban centers: a case study in Sao Paulo, Brazil. - Building and Environment Journal 144: 450-458.

[4] Altuntaş, A. (2012): Sürdürülebilir Toplumlar ve Metropollerin Baskilarindan Kurtulmak İçin Alternatif Bir Yol: Sürdürülebilir Kentler. - Mustafa Kemal Üniversitesi Sosyal Bilimler Enstitüsü Dergisi 9(17): 135-148.

[5] Beck, U. (1992): Risk Society: Towards a New Modernity. - Sage Publications, London.

[6] Bell, S. (2005): Nature for People: The Importance of Green Spaces to Communities in the East Midlands of England. - In: Kowarik, I., Körner, S. (eds.) Wild Urban Woodlands. Springer, Berlin, pp. 81-94.

[7] Bolund, P., Hunhammar, S. (1999): Ecosystem services in urban areas. - Ecological Economics 29: 293-30.

[8] Burgess, J., Harrison, C., Limb, M. (1988): Parks and the urban green: a study of popular meaning and values for open spaces in the city. - Urban Stud. 25: 455-473.

[9] Burns, G. W. (2006): Naturally Happy, Naturally Healthy: The Role of the Natural Environment. - In: Huppert, F. et al. (eds.) The Science of Well-Being. Oxford Univ. Press, Oxford, pp. 405-431.

[10] Çetinkaya, G. (2014): Doğa yürüyüşü parkurlarının turizm amaçlı değerlendirilmesi: Antalya Beydağları örneği. - Akdeniz Üniversitesi, Sosyal Bilimler Enstitüsü, Turizm İşletmeciliği ve Otelcilik Anabilim Dalı. Yayınlanmamış Doktora Tezi, Antalya.

[11] Chan, S. Y., Chau, C. K., Leung, T. M. (2017): On the study thermal comfort and perception of environmental features in urban parks: a structural equation modeling approach. - Building and Environment 122: 171-183.

[12] Chan, C. S., Si, F. H., Marafa, L. M. (2018): Indicator development for sustainable urban park management in Hong Kong. - Urban Foresty and Urban Greening Journal 31: 1-14.

[13] Chen, L., Yongyi, W., Zhang, L., Xing, W.-N. (2015): Studies of thermal comfort and space use in an urban park square in cool and cold seasons in Shanghai. - Building and Environment 94: 171-183.

[14] Chiesura, A. (2004): The role of urban parks for the sustainable city. - Landscape and Urban Planning 68: 129-138.

[15] Çınar, İ. (2008): Kent Parklarının Rekreasyonel Yönden Yeterliliği Üzerine FethiyeMuğla Kent Parkları Örneğinde Bir Araştırma. - Adnan Menderes Üniversitesi Ziraat Fakültesi Dergisi 5(2): 33-38.

[16] Conway, H. (2000): Parks and People: The Social Functions. - In: Woudstra, J., Fieldhouse, K. (eds.) The Regeneration of Public Parks. Taylor \& Francis, London, UK.

[17] DeGraaf, D. A., Jordan, D. (2003): Social capital—how parks and recreation help to build community. - Parks Recreat. 38: 20-27.

[18] Dutcher, D. D., Finley, J. C., Luloff, A. E., Johnson, J. B. (2007): Connectivity with nature as a measure of environmental values. - Environ. Behav. 39: 474-493.

[19] Ferris, J., Norman, C., Sempik, J. (2001): People, land and sustainability: community gardens and the social dimension of sustainable development. - Soc. Adm. 35: 559-568.

[20] Gehl, J., Gemzoe, L. (2001): New City Spaces. - Danish Architecture Press, Copenhagen, Danmark.

[21] Ghorbani, R. (2006): Assessing Accessibility of Urban Parks Tabriz, Iran. - Tabriz University, Tabriz.

[22] Gürbüz, H., Yılmaz, V. (2017): Eskişehir Rekreasyon Alanlarından Kentpark'ın Kullanım Tercihini Etkileyen Faktörlerin Araştırılması. - Researcher: Social Science Studies 5(9): 187-200.

[23] Grahn, P. (1985): Man's Needs for Urban Parks, Greenery and Recreation. - Swedish Agricultural University, Lomma Municipality, Sweden.

[24] Greenberg, J. S. (1985): Health and wellness: a conceptual difference. - J. Sch. Health 55: 403-406. 
[25] Hami, A., Suhardi, B. M., Manohar, M., Shahhosseini, H. (2011): Users' preferences of usability and sustainability of old urban park in Tabriz, Iran. - Aust. J. Basic Appl. Sci. 5: 1899-2011.

[26] Huseynov, F. (2005): Baku: strategy of sustainable development. - Urbanism 8: 41-53.

[27] Kaplan, R. (1983): The analysis of perception via preference; a strategy for studying how the environment is experienced, landscape planning. - Analysis 12: 161-176.

[28] Kurtaslan, B. Ö. (2017): Başarılı Kent Parkı Planlama ve Yönetimi Yaklaşımının Teardrop Park (New York) Örneğinde Araştırılması. - International Journal of Society Researches 7(13): 742-760. DOI: 10.26466/opus.354010.

[29] Kizılaslan, S. (2007): Study of Trabzon City parks and gardens in terms of landscape design criteria. - Master Thesis, Ankara University, Institute of Science, Ankara, pp. 1315.

[30] Lam, K., Ng, S., Hui, W., Chan, P. (2005): Environmental quality of urban parks and open spaces in Hong Kong. - Environmental Monitoring and Assessment 11: 55-73.

[31] Lee, Y. C., Kim, C. (2015): Attitudes of citizens towards urban parks and green spaces for urban sustainability: the case of Gyeongsan City, Republic of Korea. - Journal of Sustainability 7: 8240-8254.

[32] Li, L., Pussella, P. G. R. N. I. (2017): Is Colombo City, Sri Lanka secured for urban green space standards. - Applied Ecology and Environment Research 15(3): 1789-1799.

[33] Loures, L., Santos, R., Panagopoulos, T. (2007): Urban parks and sustainable city planning - the case of Partimao, Portugal. - WSEAS Trans. Environ. Dev. 10: 171-180.

[34] Mahrous, A. M., Moustafa, Y. M., El-Ela, M. A. (2018): Physical characteristics and perceived security in urban parks: investigation in the Egyptian context. - Ain Shams Engineering Journal 9: 3055-3066.

[35] Matz, J. N., Stieb, D. M., Brion, O. (2015): Urban-rural differences in daily time-activity patterns, occupational activity and housing characteristics. - Environment Health Journal 14: 88 .

[36] Müftüoğlu, V. (2008): Kentsel Açık-Yeşil Alan Karar ve Uygulamalarının İmar Mevzuatı Kapsamında Ankara Kenti Örneğinde İrdelenmesi. - Yüksek Lisans Tezi. Ankara Universitesi, Fen Bilimleri Enstitüsü. Ankara.

[37] Oğuz, D. (1998): Kent parkı kavramı yönünden Ankara kent parklarının kullanım olgusu üzerinde bir araG̣tırma. - Doktora Tezi, Ankara Üniversitesi Fen Bilimleri Enstitüsü, Ankara.

[38] Oktay, D. (2007):“Kentsel Kimlik ve Canlılık Bağlamında Meydanlar: Kuzey Kıbrıs”ta Bir Meydana Bakış, Mimarlık. - TMMOB Mimarlar Odası Süreli Yayını (Dosya: Kentler ve Meydanları) 334: 29-34.

[39] Onsekiz, D., Emür, S. H. (2008): Kent Parklarında Kullanıcı Tercihleri ve Değerlendirme Ölçütlerinin Belirlenmesi. - Sosyal Bilimler Enstitüsü Dergisi 24(1): 69-104.

[40] Özbilen, A. (1991): Kent İçi Açı Alanlar ve Dağılımı, Tarihi Eserler ve Gelişen Yeni Yapılaşma; Trabzon Kentinde Bir Uygulama Örneği. - KTÜ Orman Fakültesi, Genel Yayın No: 155, Fakülte Yayın No: 17, Trabzon.

[41] Özdemir, A. (2007): Urban sustainability and open space networks. - J. Appl. Sci. 7: 3713-3720.

[42] Özkır, A. (2007): Kent parkları yönetim modelinin geliştirilmesi. - Doktora Tezi, Ankara Üniversitesi Fen Bilimleri Enstitüsü, Ankara, pp. 11-24.

[43] Polat, A. T. (2006): Kent parkı kavramı ve Konya için örnek bir çalışma. - Yüksek Lisans Tezi, Selçuk Üniversitesi Fen Bilimleri Enstitüsü, Konya.

[44] Polat, A. T., Güngör, S. (2013): Konya İli Kent Parkları Kullanıcı Demografik Özellikleri ve Park Ziyareti Arasındaki İlişkiler. - Peyzaj Mimarlı̆ğ 5. Kongresi "Dönüşen Peyzaj", Adana. S: 882-893.

[45] Sachs, A. (1995): Eco-Justice: Linking Human Rights and the Environment. Worldwatch Paper 127. Worldwatch Institute, Washington, DC. 
[46] Rahimi, A. (2006): Weather Pullotion Analysis Due to Unsuitable Locating of Industrial Area in Tabriz, Iran. - Tabriz University, Tabriz.

[47] Romianfar, S. Z. (2008): Tabriz Urban Parks, El Goli. - Parks and Green Spaces Organization of Tabriz, Tabriz.

[48] Rostami, M., Zargar, R. S., Eini, H. A (2017): Reflection on the public art: comparative case study of Elgolu Park in Tabriz (Iran) and Lampini Park in Bangkok (Thailand). Bagh-e Nazar Journal 14(4)9: 57-68.

[49] Teal, M., Huang, C. S., Rodiek, J. (1998): Open space planning of Travis Country, Austin, Texas: a collaborative design. - Landscape Urban Planning 42: 259-268.

[50] Thompson, C. W. (2002): Urban open space in the 21st century. - Landscape and Urban Planning 60: 59-72.

[51] Thorsson, S., Lindquist, M., Lindquist, S. (2004): Thermal bioclimatic conditions and patterns of behaviour in an urban park in Goteborg, Sweden. - Int J Biometeorol 48: 149156. DOI: $10.1007 / \mathrm{s} 00484-003-0189-8$.

[52] Topal, A. K. (2004): Kavramsal olarak kent nedir ve Türkiye'de kent neresidir? - Dokuz Eylül Üniversitesi Sosyal Bilimler Enstitüsü Dergisi 6(1): 276-294.

[53] Tümer, S. (1976): Rekreasyon Alan Ölçütleri. - T. T. B. Planlama Dairesi Başkanlığı, Ankara.

[54] URL 1 (2018): https://s3.amazonaws.com/academia.edu.documents.

[55] Walter, V. et al. (2005): Millennium Assessment. Ecosystems and Human Well-Being: A Framework for Assessment. - Millennium Ecosystem Assessment Series. Island Press, Washington, DC, USA.

[56] Waterman, T., Wall, E. (2009): Urban Design. - AVA Publishing, Worthing, UK.

[57] Wilber, D. N. (1979): Persian Gardens and Garden Pavilions. - National Academy Press, Washington, DC.

[58] World Health Organization (WHO) (2018): Constitution of the World Health Organization. - WHO, Geneva, Switzerland.

[59] Yazıcı, B. F (2015): Kentsel Açık-Yeşil Alanların Sağladığı Ekosistem Hizmetleri. KTÜ Fen Bilimleri Enstitüsü, Y. Lisans Tezi, Trabzon.

[60] Yazgan, M. E., Khabbazi, P. A. (2013): Green cities. - Journal of Tekirdağ Agriculture Faculty 10(1): 99-104.

[61] Y1lmaz, S. Zengin, M. Demircioğlu, N. (2007): Determination of user profile at city parks: a sample from Turkey. - Building and Environment 42: 2325-2332.

[62] Zaloğlu, A. (2006): Study of water as show element in Ankara City parks. - Master Thesis, Ankara University, Institute of Science, Ankara.

[63] Zhang, B., Xie, G., Zhang, C., Zhang, J. (2012): The economic benefits of rainwaterrunoff reduction by urban green spaces: a case study in Beijing, China. - Journal of Environmental Management 100: 65-71. 